\title{
U Waves by ECG Finding
}

National Cancer Institute

\section{Source}

National Cancer Institute. U Waves by ECG Finding. NCI Thesaurus. Code C71089.

An electrocardiog raphic finding of a small hump following the T wave occurring during the final phase of Purkinje repolarization. 